ZOOLOGIA 29 (5): 413-419, October, 2012

doi: $10.1590 /$ S1984-46702012000500004

\title{
Latitudinal disparity in the reproductive cycle of sharpnose shark, Rhizoprionodon lalandii (Elasmobranchii: Carcharhinidae), in Atlantic waters off South America
}

\author{
Morgana M. Macedo' ${ }^{1}$ Marcia F. Sousa ${ }^{1} \&$ Vandick S. Batista ${ }^{1,2}$ \\ ${ }^{1}$ Laboratório de Ecologia, Peixes e Pesca, Instituto de Ciências Biológicas e da Saúde, Universidade Federal de Alagoas, \\ Campus A.C. Simões. Avenida Lourival Melo Mota, Tabuleiro do Martins, 57072-970 Maceió, AL, Brazil. \\ ${ }^{2}$ Corresponding author. E-mail: vbatista@pq.cnpq.br
}

\begin{abstract}
Geographical variation in biophysical conditions may strongly influence the life history characteristics of widely distributed species, such as the Brazilian sharpnose shark, Rhizoprionodon lalandii (Müller \& Henle, 1839). Here, we use original and secondary data of reproductive traits of $R$. lalandii to identify population differences among northern/northeastern and southern Atlantic waters of South America. In the southeast region, birth occurs between December and March, and the young become frequent along the coast between April and September. Mating occurs mainly between March and June, when females with bite marks are common. Females in early pregnancy occur between March and September. The reproductive cycle of $R$. lalandii in the northern/northeastern region was approximately six months ahead of the cycle described for the southeastern region. These results support the hypothesis that environmental conditions in the North-Northeast and Southeast generate differences in life history traits, resulting in at least two distinct populations along the Brazilian coast.
\end{abstract}

KEY WORDS. Coastal waters; life history; reproductive traits; northeastern Brazil.

Some ife history traits, such as life spans, are a phenotypic expression of the interaction between genotype and the environment (BEGg 2005). Thus, geographic variation in the biophysical environment may exert considerable influence over the life history traits expressed by geographically disjunct populations of the same species (Roff 2002). This effect can be clearly seen in the marine environment, where prevailing currents and geographically situated climatic processes can generate distinct biophysical differences between closely adjacent areas of the sea (Spalding et al. 2007).

In the case of the elasmobranchs, population differences have been regularly observed among groups of individuals of widely distributed species (Parsons 1993, Carlson \& Baremore 2003, NeEr \& Thompson 2005, CARLson et al. 2006), possibly as a consequence of geographic differences in environmental conditions. Some elasmobranch species can be found throughout the central-south American marine coast. For example, the Brazilian sharpnose shark, Rhizoprionodon lalandii (Müller \& Henle, 1839), is distributed from south of Mexico to Uruguay (Figueiredo 1977, Compagno 1984, Gallo et al. 2010). Somewhat unusually for a Neotropical elasmobranch species, detailed information exists concerning the reproductive cycle of $R$. lalandii in the Southeast and northern regions of Brazil (FERREIRA 1988, Lessa 1988, Motta et al. 2005, 2007, Andrade et al. 2008). Moreover, there appears to be considerable divergences in the re- productive cycle between these regions (Lessa 1988), suggesting that these populations may be reproductively isolated.

The present paper tests the null hypothesis that there is only one population of $R$. lalandii along the tropical and subtropical Atlantic coast of South America based on the reproductive parameters of individuals from different sub-regions.

\section{MATERIAL AND METHODS}

Specimens were collected between January 2006 and November 2008, along approximately $160 \mathrm{~km}$ of the northeastern coast of Brazil, where the commercial fishing fleet of Maceió operates $\left(9^{\circ} 38^{\prime} \mathrm{S}, 35^{\circ} 39^{\prime} \mathrm{W}\right.$ to $\left.9^{\circ} 59^{\prime} \mathrm{S}, 35^{\circ} 55^{\prime} \mathrm{W}\right)$. All biological samples were collected at the fishing harbor of Jaraguá in Maceió $\left(9^{\circ} 40^{\prime}\right.$ S, $35^{\circ} 43^{\prime} \mathrm{W}$ ) (Fig. 1).

The fishing gear included gillnets $(1.8 \mathrm{~km}$ long, 1.5 to 3 $\mathrm{m}$ in height, with 40 to $60 \mathrm{~mm}$ twine diameter, 35 to $60 \mathrm{~mm}$ mesh size between opposed knots) and hand lines (hook number 14 to 17, baited with pieces of rays and green moray eels Gymnothorax spp. or tuna Katswonus spp.). The fishing ground varied in depth from two to $48 \mathrm{~m}$, although catches of $R$. lalandii were only taken between 10 to $48 \mathrm{~m}$ deep.

Analyses were based on 93 specimens of $R$. lalandii. Specimens were classified as: 1) head, 2) carcass (without viscera), or 3) whole. This classification was necessary because some speci- 


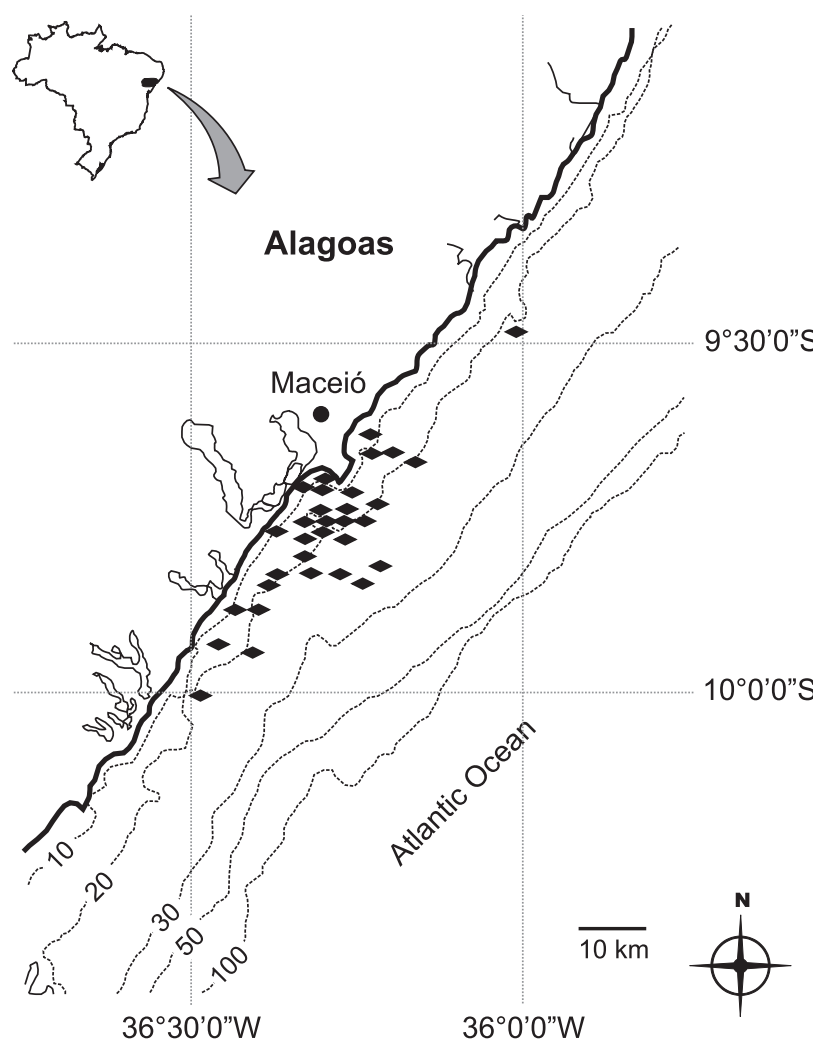

Figure 1. Map of Alagoas coast with the indication of fishing grounds used to exploit sharks by the commercial fleet.

mens were missing their entire body or without viscera due to fishermen choices. Morphometric variables are presented in Table I and were used to convert data in total length for comparative purposes (when total length could not be directly measured). Species were identified according to Figueiredo (1977), Compagno (1984) and Carpenter (2002). A voucher specimen was deposited in the Museu of Natural History collection under the code MUFAL1651.

Clasper length and rigidity were recorded in males. The degree of stiffness was used to classify the degree of male maturity according to the following criteria: decalcified (immature); partially calcified (in maturation); and totally calcified (mature). The presence of seminal liquid was not recorded. Both uteri were longitudinally sectioned in females to record their contents. Ovarian follicle activity was analyzed according to number, size and color. The presence of eggs or embryos in the uterus and their development stage were used to classify the stage of female maturity: immature (filiform uterus, low developed ovary, without evidence of follicular activity); mature (filiform uterus, ovary with evidence of follicular activity); pregnant (uterus with eggs or embryos); and postpartum (uterus empty and extended) (Hazin et al. 2002).
Regression analysis was performed using total length data (TL) and other morphometric variables (Tab. I) for specimens in good physical condition, in order to provide allometric equations to estimate the TL of all partial specimens. The size at first sexual maturity $\left(\mathrm{L}_{50}\right)$ was estimated separately for males and females by adjusting a logistic model (KING 1995): $\mathrm{L}_{50}=[1$ $\left.+\exp \left(-\mathrm{b}\left(\mathrm{L}_{\mathrm{i}}-\left(-\mathrm{a}^{*} \mathrm{~b}^{-1}\right)\right)\right)\right]^{-1}$, where: $\mathrm{L}_{50}=$ length at first sexual maturity; $\mathrm{L}_{\mathrm{i}}=$ middle point at length class $\mathrm{i}$; and $\mathrm{a}, \mathrm{b}=$ constants.

The size at birth was estimated from the largest embryo size recorded and the smaller neonates caught in the area or recorded in the literature.

Table I. Morphometric variables recorded according to the fishes collected.

\begin{tabular}{ll}
\hline \multicolumn{1}{c}{ Material collected } & \multicolumn{1}{c}{ Variable (mm) } \\
\hline Head & Head Width (HW) \\
& Orbital Diameter (OD) \\
& Pre-Oral Length (POL) \\
& Mouth Width (MW) \\
& Labial Superior Sulcus Length (LSSL) \\
& Inter-Nasal Length (INL) \\
& Body Length (BL) \\
Body & All listed above \\
Whole & Total Length (TL) \\
& Intermediary Length (IL) \\
\hline
\end{tabular}

\section{RESULTS}

A total of 93 R. lalandii specimens were collected, consisting of $5.4 \%$ neonates, $12.9 \%$ young, and $81.7 \%$ adults. Pregnant females accounted for $8.6 \%$ of all specimens collected and $47.0 \%$ of female specimens were obtained in an intact physical state.

The best fit linear model used to estimate the total length of partial specimens was obtained for the relation between the $\mathrm{TL}$ and the Pre-oral Length (POL) and the resulting equation: $\mathrm{POL}=0.0583 \mathrm{TL}+0.8572(\mathrm{r}=0.9164, \mathrm{p}>0.05)$

The total length of specimens varied between 29.6-85.7 $\mathrm{cm}$ for males and 30.8-88.1 cm for females (Fig. 2). The total weight varied between 60-2,700 g. The smallest specimen caught was $29.6 \mathrm{~cm}$ TL and the largest fully developed embryo near term was $28.2 \mathrm{~cm}$ TL.

The sex ratio was 1:0.5 from September to December $\left(\chi^{2}\right.$ $=0.333 ; \mathrm{p}>0.05), 1: 2.66$ from January to March $\left(\chi^{2}=2.273, \mathrm{p}\right.$ $>0.05), 1: 1.16$ from April to June $\left(\chi^{2}=0.077, p>0.05\right)$ and $1: 1.23$ from July to September $\left(\chi^{2}=0.310, p>0.05\right)$. The general sex-ratio was $1: 1.33\left(\chi^{2}=1.143, \mathrm{p}>0.05\right)$.

Vitellogenic follicles were found in females larger than $50.2 \mathrm{~cm} \mathrm{TL}$, and $\mathrm{L}_{50}$ was estimated to be at $65 \mathrm{~cm} \mathrm{TL}$ - both sides of ovaries and uteri are functional. The smallest pregnant 


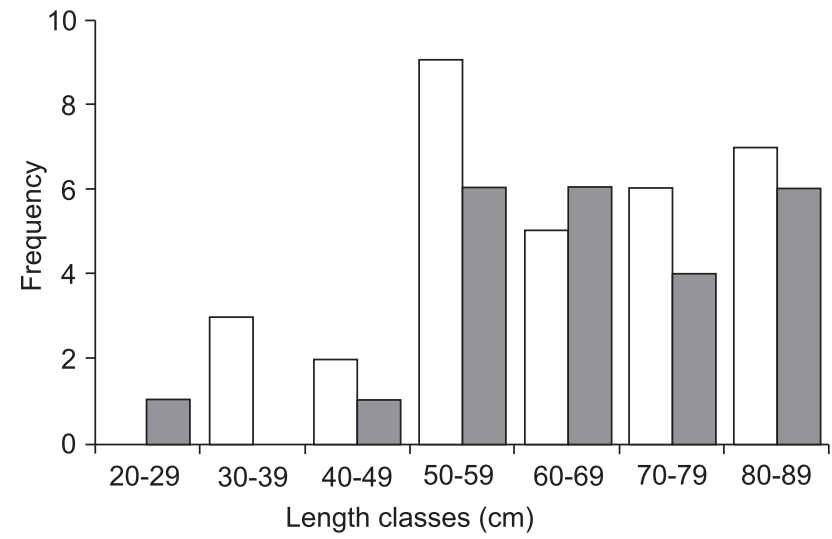

Figure 2. Length frequency distribution of $R$. lalandii in the coast of Alagoas, northeast Brazil. Males (gray) and females (white). $N=56$.

female was $57.9 \mathrm{~cm}$ TL. Two to four embryos were found in pregnant females. This study did not reveal any relationship between female fertility and total length. The smallest mature male was $65 \mathrm{~cm} \mathrm{TL}$ and $\mathrm{L}_{50}$ was estimated at $72.5 \mathrm{~cm}$ TL.

Neonates were recorded in high frequencies from December to March in catches from $10 \mathrm{~m}$ to $30 \mathrm{~m}$ deep. Immature specimens were more frequent between April and September (Fig. 3), particularly in catches near the $10 \mathrm{~m}$ isobath. Adults were captured throughout the year in the area; at depths between 10-19 m from the end of March to August (rainy season), and 20-39 $\mathrm{m}$ from December to February (Figs 4 and 5). The largest records of pregnant females occurred from March to September, reaching a peak in this last month $(\mathrm{N}=6)$. However, all embryos were small. Females with full-term embryos were recorded only between December and March. During this period there were also the most frequent records of females with follicular activity (Fig. 6). Males caught from March to June were sexually mature, with higher values of gonadal weight in $\operatorname{March}(\mathrm{N}=5)$.

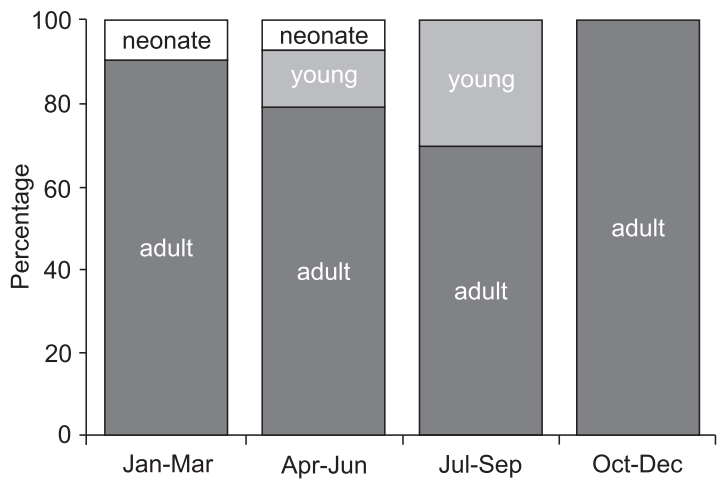

Figure 3. Seasonal distribution by development stages of $R$. lalandii caught in the coast of Alagoas, northeast Brazil $(N=93)$.
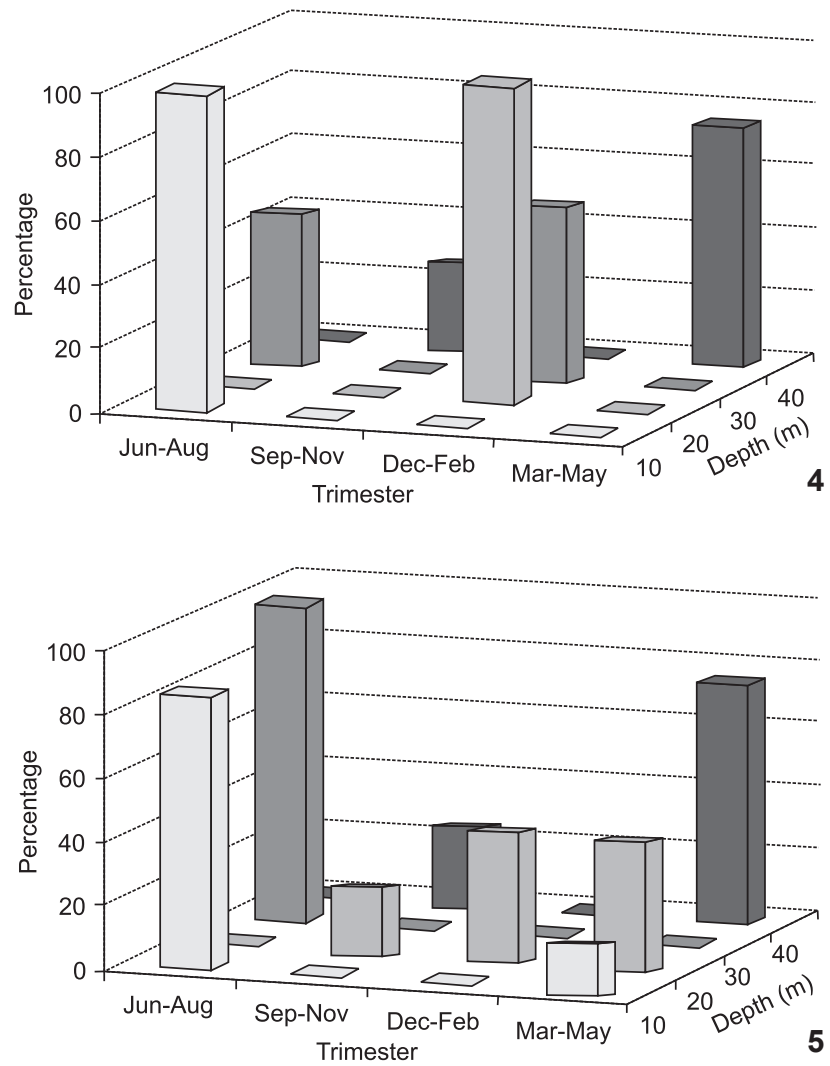

Figures 4-5. Spatial distribution of $R$. lalandii adults in depth classes throughout the year for (4) females and (5) males. $(N=42)$.

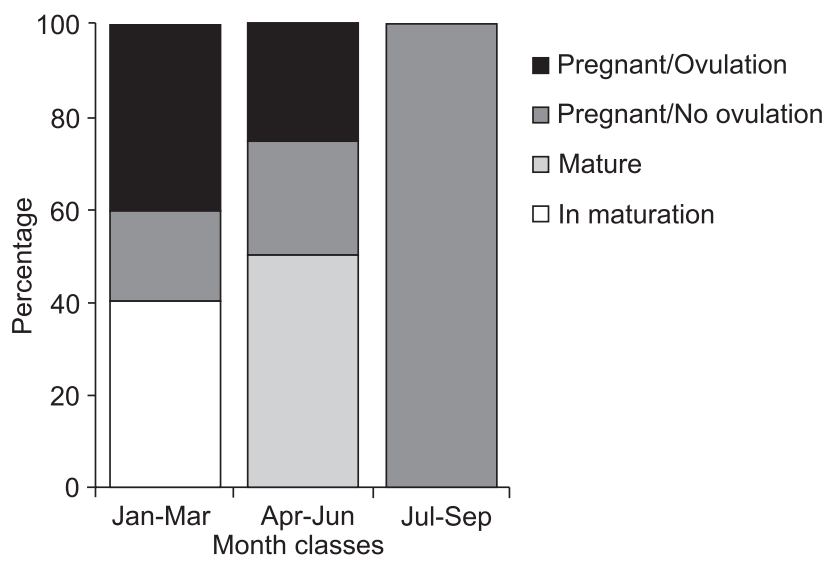

Figure 6. Annual frequency of $R$. lalandii adult females in northeast South American waters $(n=12)$.

\section{DISCUSSION}

The results recorded, for total length, size of sexual maturity, and smallest pregnant females differ from those found for 
the southern population in the Atlantic waters off South America (Tab. II). The largest specimen previously reported in the literature for southern Brazilian waters measured $80 \mathrm{~cm}$ (МоттA et al. 2007), a smaller size when compared with the $88.1 \mathrm{~cm}$ specimen reported here. Because $R$. lalandii is an ectothermic species, we expect it to conform to a converse Bergmann cline (BLANCKENHORN \& Demont 2004), with body size decreasing toward the poles. However, sampling methodologies affect such comparisons, and our conclusion should be treated with caution.

Males that are larger than females have not been commonly found in elasmobranchs, although there are some exceptions, such as species of Rhizoprionodon (MACHADo et al. 2001, Loefer \& Sedberry 2003, Henderson et al. 2006). The relatively small sample size of males means that our result should also be treated cautiously. The sizes at first sexual maturity and first gestation of females recorded in northern/northeastern regions of South America were smaller than those recorded in the Southeast (Ferreira 1988, Lessa 1988, Motta et al. 2007, Andrade et al. 2008, Lessa et al. 2009). Higher mean water temperatures can affect not only enzymatic processes, but also size at gonadal maturation and the total length reached by individuals (BEGON et al. 2006). In northern/northeastern regions, mean water temperature varies between 26 and $28^{\circ} \mathrm{C}$, reaching up to $30^{\circ} \mathrm{C}$ in the coastal waters of Maranhão. Meanwhile, in southeastern waters, these temperatures vary between 15 to $18^{\circ} \mathrm{C}$ (Lessa 1988). Such observations support the observations of MeNNI \& Lessa (1988) and FerReira (1988) that reproductive traits in Brazilian elasmobranchs may be closely related to differences in water temperature. However, the effects of temperature on the reproduction and growth of elasmobranchs are so complex and so dependent on other environmental variables that direct experiments are required to confirm this hypothesis.
Larger sizes at maturation in temperate regions when compared with tropical regions are predicted by latitudinal theory (Lombardi-Carlson et al. 2003, Colonello et al. 2006). Small scale spatial differences may not clearly show this effect, but large scale differences in populations separated into different biogeographic regions may generate conditions for the expression of these differences.

The presence of neonates and females with full-term embryos (with a size near to birth weight) indicates that $R$. lalandii are typically born between December and March in northeastern South America. The increased number of young specimens caught from April to September confirms this hypothesis. Mating probably occurs mainly from March to June, when large numbers of mature, but not pregnant, females, were recorded. In this period the presence of females with bite marks was common. This interpretation was also confirmed by the fact that early pregnant females were found only from March to September.

Ferreira (1988), MotTa et al. $(2005,2007)$ and Andrade et al. (2008) suggest that in southeastern waters, the birth of $R$. lalandii individuals occur between July and September (winter). In the North, the reproductive cycle of $R$. lalandii is still largely undetermined (LESSA 1988), although fully developed embryos had previously been found only between August and December. This indicates that birth would be close to this period (January to March). Data presented in this paper supports this hypothesis.

Thus, the timing of the reproductive cycle of northern/ northeastern populations of $R$. lalandii seems to be clearly different from the cycle of the population in southeastern waters (Tab. III). This difference could be related to environmental differences between the regions. Unlike what happens in the

Table II. Comparison between total length of $R$. lalandii for different regions in Brazil.

\begin{tabular}{cccll}
\hline Total length interval $(\mathrm{cm})$ & Size of sexual maturity $(\mathrm{cm})$ & Smallest pregnant female $(\mathrm{cm})$ & \multicolumn{1}{c}{ Region } & \multicolumn{1}{c}{ Reference } \\
\hline $29.6-88.1$ & $\mathrm{M}-72.5 \mathrm{~F}-65.0$ & 57.9 & Alagoas & Current research \\
$40.0-72.0$ & $\mathrm{M}-52.0 \mathrm{~F}-56.0$ & $53.0-56.0$ & Maranhão & LESSA (1988) \\
$34.0-75.0$ & $\mathrm{M}-60.0 \mathrm{~F}-65.0$ & - & Rio de Janeiro & FERREIRA (1988) \\
$30.0-80.0$ & $\mathrm{M}-59.0 \mathrm{~F}-62.0$ & 65.0 & São Paulo & MotTA et al. (2007) \\
\hline
\end{tabular}

Table III. Comparison of the major incidence of some traits of the reproductive cycle of $R$. lalandii between North and South Atlantic waters.

\begin{tabular}{|c|c|c|}
\hline \multirow{2}{*}{ Information } & \multicolumn{2}{|c|}{ Source } \\
\hline & Present paper & MotтA et al. (2007) \\
\hline Neonates & January to March & August to September \\
\hline Young fish & April to September & October to March \\
\hline Adults & April to June & April to September \\
\hline Pregnancy at the beginning of embryo development & April to September & October to February \\
\hline Pregnancy with fully developed embryos & January to March & July to September \\
\hline Length of reproductive cycle & 12 months & 11-12 months \\
\hline
\end{tabular}

ZOOLOGIA 29 (5): 413-419, October, 2012 
Northeast, in southeastern waters the population dynamics is usually strongly affected by temperature oscillations, with the worst conditions for reproduction and growth occurring during the winter.

Rainfall may also be significant. It is the main variable affecting the nutrient levels and turbidity of coastal waters, changing the primary production of coastal waters and therefore influencing fish population dynamics and behavior (CHAGAs et al. 2006). Moreover, in southeastern Brazil, there is a coastal upwelling phenomenon, with effects from Cabo Frio to Cape Santa Marta Grande. This is responsible for the great fishing productivity in the region, and is caused by water over the nutrient-rich bottom rising to fill the surface water that is displaced offshore (ARAgão \& Teixeira 1980, Fernandes et al. 2012). This process can increase growth and reduce mortality in shark populations (McPhiE \& CAMPANa 2009), and represents favorable conditions for the survival of newborns and for mating (CHAGAs et al. 2006). The aggregation of adults was observed at a depth around $10 \mathrm{~m}$ during the rainy season (March to September), which could be related to increased local productivity (CHAGAs et al. 2006). Extra feed input could aid in the recovery of energy expended during mating, and provide energy reserves for gestation.

No sex-ratio was significantly different from the expected $1: 1$, so the hypothesis of sexual segregation by females (SADOwSKY 1967) was not validated for this species. It is common amongst sharks that females migrate to deeper waters during gestation, and that males remain in shallow waters (SADOwsKY 1967), but it does not seem to be the case of this species.

The presence of neonates at depths from 10 to $30 \mathrm{~m}$ and the high frequency of pregnant females carrying large embryos in the dry season indicate that these waters are used as nurseries (MotTA et al. 2005, 2007, ANDrade et al. 2008). Elasmobranch nurseries are normally found in coastal areas with reduced risks from predators and favorable conditions for the growth of juveniles. These areas are usually shallow, protected, and abundant in food resources (Үокота \& Lessa 2006). In these conditions the vulnerable young specimens can grow relatively fast and are able to rapidly join the adult part of the population.

Nurseries can be classified as primary and secondary (BASs 1978, SimpFendorfer \& Milward 1993), but they can also be classified according to their exposure level to predators. In this case, the classification is in the categories protected - areas with low adult frequency - and unprotected - areas inhabited by adults (BRANSTETTER 1990, Sims 2003). Rhizoprionodon lalandii appears to use the northeastern coastal area as primary and secondary nurseries, since neonates and juvenile sharks have been found in the same depths. The presence of adult specimens in the same depths would leave nurseries unprotected. However, populations of species of the genus do not seem to be limited by predation (CARLSOn et al. 2008), and cannibalism has not been commonly observed in Rhizoprionodon species (e.g. Silva \& AlmeIDa 2001, HOFFMAYER \& PARSONs 2003) making this hypothesis unlikely.
Our results support the hypothesis of MоттA et al. (2005, 2007) and ANDRADE et al. (2008) that the oceanographic conditions of the northern/northeastern and southeastern regions generate differences in biological parameters among fish populations and result in at least two distinct stocks along the Brazilian coast. The authors recommend other comparative studies to better identify whether these variations are caused by changes in phenotypic or genetic differences. Rhizoprionodon lalandii has been classified as vulnerable (Rosa et al. 2004), but given the existence of distinct population units, some genetically distinct sub-populations may be in a critical state. Clearly, it is important to better evaluate the status of these apparently distinct populations and to generate enough information for the development of effective conservation and management plans for elasmobranchs in Brazilian coastal waters.

\section{ACKNOWLEDGEMENTS}

Universidade Federal de Alagoas (UFAL) provided research conditions and IBAMA provided collection permissions (under V.S.B.). J. Rangely, C. Tiburtino and fishermen Josias, Môa, Tarzan, Carapicú, Pedro and Romildo assisted in field collections. We thank N.N. Fabré, R.L. Ladle and anonymous reviewers for comments on the manuscript. Conselho Nacional de Desenvolvimento Científico e Tecnológico (CNPq) and Coordenadoria de Pessoal de Ensino Superior (CAPES) provided funding for this study.

\section{LITERATURE CITED}

Andrade, A.C.; L.C. Silva-Júnior \& M. Vianna. 2008. Reproductive biology and population variables of the Brazilian sharpnose shark Rhizoprionodon lalandii (Müller \& Henle, 1839) captured in coastal waters of south-eastern Brazil. Journal of Fish Biology 72: 473-484. doi:10.1111/j.1095-8649.2007.01706.x.

Aragão, E.A \& C. Teixeira. 1980. Produção primária e concentração de clorofila-a na costa brasileira (lat. 220 31's - long. 410 s2'w a lat. 28043 's - long. 470 s7'w). Boletim do Instituto Oceanográfico de São Paulo 29: 9-14.

BASS, A.J. 1978. Problems in studies of sharks in the southwest Indian Ocean, p. 545-594. In: E.S. Hogdson \& R.F. MATHEwson (Eds). Sensory Biology of Sharks, Skates and Rays. Arlington, Office of Naval Research Department of Navy.

BEGG, G.A. 2005. Life history parameters, p. 119-150. In: S.X. CADRIN; K.D. Friedland \& J.R. WALDMAN (Eds). Stock identification methods: applications in fishery science. Oxford, Elsevier Academic Press.

Begon, M.; J.L. Harper \& C.R. Townsend. 2006. Ecology: From individuals to ecosystems. Oxford, Blackwell Publishing.

Blanckenhorn, W.U. \& M. Demont. 2004. Bergmann and Converse Bergmann Latitudinal Clines in Arthropods: Two Ends of a Continuum? Integrative \& Comparative Biology 44: 413-424. BRAnstetter, S. 1990. Early life-history implications of selected Carcharhinoid and Lamnoid sharks of the Northwest 
Atlantic. NOAA Technical Report NMFS 90: 17-28.

Carlson, J.K. \& I.E. Baremore. 2003. Changes in biological parameters of Atlantic sharpnose shark Rhizoprionodon terraenovae in the Gulf of Mexico: evidence for densitydependent growth and maturity? Marine and Freshwater Research 54: 227-234. doi:10.1071/MF02153

Carlson, J.K.; J.R. Sulikowski \& I.E. Baremore. 2006. Do differences in life history exist for blacktip sharks, Carcharhinus limbatus, from the United States South Atlantic Bight and Eastern Gulf of Mexico? Environmental Biology of Fishes 77: 279-292. doi: 10.1007/s10641-006-9129-X

Carlson, J.K.; M.R. Heupel; D.M. Bethea \& L.D. Hollensead. 2008. Coastal Habitat Use and Residency of Juvenile Atlantic Sharpnose Sharks (Rhizoprionodon terraenovae). Estuaries and Coasts 31: 931-940. doi: 10.1007/s12237-008-9075-2.

CARPENTER, K.E. 2002. The living marine resources of the Western Central Atlantic. Introduction, molluscs, crustaceans, hagfishes, sharks, batoid fishes, and chimaeras. In: FAO Species Identification Guide for Fishery Purposes and American Society of Ichthyologists and Herpetologists Special Publication 5. Rome, FAO, vol. 1.

Chagas, L.P.; J.C. Joyeux \& F.R. Fonseca. 2006. Small-scale spatial changes in estuarine fish: subtidal assemblages in tropical Brazil. Journal of Marine Biological Association of the United Kingdom 86: 861-875. doi: 10.1017/S0025315406013804

Colonello, J.H; L.O. Lucifora \& A.M. Massa. 2006. Reproduction of the angular shark (Squatina guggenhein): geographic differences, reproductive cycle, and sexual dimorphism. ICES Journal of Marine Science 64: 131-140. doi: 10.1093/ icesjms/fs1004

Compagno, L.J.V. 1984. FAO Species catalogue. In: Sharks of the world: An annotated and illustrated catalogue of sharks species known to date. Part 2 Carcharhiniformes. FAO Fisheries Synopsis 125 (4) Part 2: 251-665.

Fernandes, L.D.A.; J. Quintanilha; W. Monteiro-Ribas; E. GonzalezRodriguez \& R. Coutinho. 2012. Seasonal and interannual coupling between sea surface temperature, phytoplankton and meroplankton in the subtropical south-western Atlantic Ocean. Journal of Plankton Research 34 (3): 236-244.

FerReIRA, B.P. 1988. Ciclo reprodutivo de Rhizoprionodon lalandei (Valenciennes) e $R$. porosus (Poey) (Selachii, Carcharhinidae) na região de Barra de Guaratiba. RJ. Anais da Academia Brasileira de Ciências 60: 91-101.

Figueiredo, J.L. 1977. Manual de peixes marinhos do sudoeste do Brasil. I. Introdução: Cações, raias e quimeras. São Paulo, Museu de Zoologia, USP.

Gallo, V.; M.J. Cavalcanti; R.F.L. Silva; H.M.A. Silva \& D. Pagnoncelli. 2010. Panbiogeographical analysis of the shark genus Rhizoprionodon (Chondrichthyes, Carcharhiniformes, Carcharhinidae). Journal of Fish Biology 76: 1696-1713. doi:10.1111/j.1095-8649.2010.02609.x

Hazin, F.H.V.; P.G. Oliveira \& M.K. Broadhurst. 2002. Reproduction of the blacknose shark (Carcharhinus acronotus) in coastal waters off northeastern Brazil. Fishery Bulletin 100: $143-148$.

Henderson, A.C.; J.L. Mcilwain; H.S. Al-Oufi \& A. Mbu-Ali. 2006. Reproductive biology of the milk shark Rhizoprionodon acutus and the bigeye houndshark Iago omanensis in the coastal waters of Oman. Journal of Fish Biology 68: 1662-1678. doi: 10.1111/j.1095-8649.2006.01011.x

Hoffmayer, E.R. \& G.R. Parsons. 2003. Food habits of three shark species from the Mississippi Sound in the northern Gulf of Mexico. Southeastern Naturalist 2: 271-280.

KING, M. 1995. Fisheries biology, assessment and management. Oxford, Fishing News Books, Blackwell Science.

Lessa, R.P. 1988. Premières observacions sur la biologie reproductive de Rhizoprionodon lalandii (Valenciennes, 1839) (Pisces, Carcharhinidae) de la côte nord du Brésil- Maranhão. Revista Brasileira de Biologia 48: 721-730.

Lessa, R.P.; F.M. Santana \& Z.S. Almeida. 2009. Age and growth of the Brazilian sharpnose shark, Rhizoprionodon lalandii and Caribbean sharpnose shark, R. porosus (Elasmobranchii, Carcharhinidae) on the northern coast of Brazil (Maranhão). Pan-American Journal of Aquatic Sciences 4 (4): 532-544.

Loefer J.K. \& G.R. Sedberry. 2003. Life history of the Atlantic sharpnose shark (Rhizoprionodon terraenovae) (Richardson, 1836) off the southeastern United States. Fishery Bulletin 101: 75-88.

Lombardi-Carlson, L.A.; E. Cortes; G.R. Parsons \& C.A. Manire. 2003. Latitudinal variation in life-history traits of bonnethead sharks, Sphyrna tiburo, (Carcharhiniformes: Sphyrnidae) from the eastern Gulf of Mexico. Marine and Freshwater Research 54: 875-883. doi: 10.1071/MF03023

Machado, M.R.B.; Z.A. Silva; A.C.L. Castro. 2001. Estudo da biologia reprodutiva de Rhizoprionodon porosus Poey, 1861 (Condrichthyes: Carcharhinidae) na plataforma continental do estado do Maranhão, Brasil. Boletim do Laboratório de Hidrobiologia 13: 51-65.

McPhie, R.P. \& S.E. Campana. 2009. Bomb dating and age determination of skates (family Rajidae) off the eastern coast of Canada. ICES Journal of Marine Science 66: 546-560. doi: 10.1093/icesjms/fsp002

MenNI, R.C. \& R.P. Lessa. 1998. The chondrichthyan community off Maranhão (northeastern Brazil) II. Biology of species. Acta Zoologica Lilloana 44: 69-89.

MotTA, F.S.; O.B.F. Gadig; R.C. Namora \& M.S. Braga. 2005. Size and sex compositions, length-weight relationship, and occurrence of the Brazilian sharpnose shark, Rhizoprionodon lalandii, caught by artisanal fishery from southeastern Brazil. Fisheries Research 74: 116-126. doi: 10.1016/j.fishres.2005.03.010

MotTa, F.S.; R.C. Namora; O.B.F. Gadig \& F.M.S. Braga. 2007. Reproductive biology of the Brazilian sharpnose shark (Rhizoprionodon lalandii) from southeastern Brazil. ICES Journal of Marine Science 64: 1829-1835. doi: 10.1093/icesjms/fsm159

NeER, J.A. \& B.A. Thompson. 2005. Life history of the cownose ray, Rhinoptera bonasus, in the northern Gulf of Mexico, with 
comments on geographic variability in life history traits. Environmental Biology of Fishes 73: 321-331. doi: 10.1007/s10641-005-2136-5

Parsons, G.R. 1993. Geographic variation in reproduction between two populations of the bonnethead shark, Sphyrna tiburo. Environmental Biology of Fishes 38: 25-35. doi: 10.1007/BF00842901

Rosa, R.S.; O.B.F Gadig; F. Santos Motta \& R.C. Namora. 2004. Rhizoprionodon lalandii. In: IUCN (Ed.). IUCN Red List of Threatened Species. Version 2012.1, available online at: www.iucnredlist.org [Accessed: 16/VIII/2012].

Roff, D. 2002. Life history evolution. New York, Sinauer, 465 p.

SAdowsky, V. 1967. Selachier aus dem litoral von São Paulo, Brazilien. Studies on Neotropical Fauna and Environment 5: 71-88.

Simpfendorfer, C.A. \& N.E. Milward. 1993. Utilisation of a tropical bay as a nursery area by sharks of the families Carcharhinidae and Sphyrnidae. Environmental Biology of Fishes 37: 337-345.

Sims, D.W. 2003. Tractable models for testing theories about natural strategies: foraging behavior and habitat selection of free-ranging sharks. Journal of Fish Biology 63 (Suppl. A): 53-73. doi: 10.1046/j.1095-8649.2003.00207.x

Silva C.M.L. \& Z.S. Almeida. 2001. Alimentação de Rhizoprionodon porosus (Elasmobranchii: Carcharhinidae) da costa do Maranhão, Brasil. Boletim do Instituto de Pesca 27: 201207.

Spalding, M.D.; H.E. Fox; G.R. Allen; N. Davidson; Z.A. Ferdaña; M.A.X. Finlayson; B.S. Halpern; M.A. Jorge; A.L. Lombana; S.A. Lourie; K.D. Martin; E. McManus; J. Molnar; C.A. Recchia \& J. Robertson. 2007. Marine Ecoregions of the World: A Bioregionalization of Coastal and Shelf Areas. BioScience 57: 573-583.

ҮокотA, L. \& R.P. LeSSA. 2006. A nursery area for sharks and rays in northeastern Brazil. Environmental Biology of Fishes 75: 349-360. doi: 10.1007/s10641-006-0038-9

Submitted: 17.XII.2011; Accepted: 14.IX.2012.

Editorial responsibility: Cassiano Monteiro Neto 